\title{
SOME OBSERVATIONS ON THE STATUS OF CUBA.
}

The status of Cuba since the ratification of the Treaty of Paris is anomalous, and viewed as a whole it might be called unique, could this distinction be safely applied to any political condition.

I venture some observations upon several features of the sit. wation, in the hope of making a contribution toward a right understanding of the position of $\mathrm{Cuba}$ and the responsibilities of the United States in its regard.

\section{I.}

The first paragraph of Article First of the Treaty of Paris reads: "Spain relinquishes all claim of sovereignty over and title to Cuba." Here is a parting with territory by Spain, yet there is no cession, nor even a surrender in the sense of a transfer. At the end of the peace negotiations Spain did what, at their commencement, she protested could not be done-she abandoned Cuba, after vainly striving to induce the United States to accept it from her hands. But the island, though abandoned, did not become a derelict, being straightway occupied, although not annexed, by the United States.

In these circumstances Cuba remains as foreign to our domestic system as it was when under the dominion of Spain. It is not within the purview of the Constitution nor any law of the United States. It is not within the jurisdiction of Congress, which is the legislature of the United States and not of any other country. This limitation of congressional power is prescribed by the rule that the acts of a legislature have no force in foreign territory, except, of course, as they may be held to affect citizens abroad. This rule is sometimes stated in terms recognizing the inability of one state to depreciate the sovereignty of another by asserting jurisdiction in the latter's territory, and were this the whole reason for the rule there might be difficulty in applying it to Cuba, where there is no state to be depreciated. But the sufficient reason for the rule is that a legislature is positively without jurisdiction beyond the limits of the country in which it is sovereign. 
The second paragraph of Article First of the Treaty of Paris reads: "And as the island is, upon its evacuation by Spain, to be occupied by the United States, the United States will solong as such occupation shall last, assume and discharge the obligations that may, under international law, result from the fact of its occupation, for the protection of life and property."

In considering the nature and effect of this occupation from the standpoints of the different parties interested in Cuba we shall gain an approximate idea of the status of the island.

II.

From the standpoint of the United States Cuba is a foreign country in our occupation and control.

The occupation is not beneficial to us as it would be, presumably, had we annexed the island. In fact, it is decidedly burdensome, a vexatious result of a costly war waged for the avowed purpose of freeing Cuba from Spain in order to turn it over to its own people. However this fact may be esteemed in foreign chancelleries, or in Cuba itself, it entitles the United States to assert, upon occasion, any right, privilege or immunity that enures to a disinterested occupant of territory as distinguished from a sovereign proprietor, and leaves them responsible only for the discharge of the specific obligations of the Treaty of Paris, and such duties, sufficiently onerous, as may be attached by international law to an occupation of this peculiar kind.

Our control over Cuba savors of the protectoral relation in important respects, yet it is not a protectorate, because, apart from uncivilized regions, the subject of this relation is a state of more or less substantial powers.

There is no state of Cuba, and we shall only add to the embarrassments of a sufficiently difficult problem by tolerating such fictions as an embryo state, or even an effective sovereignty in the Cuban people. It is true that there are in operation in the island municipal and provincial systems of government and a complete judicial system, all officered by Cubans, but these agencies do not emanate from a local sovereignty. They exist by the ordination or permission of the United States. To be short, whatever sovereignty there is in Cuba to-day is vested in the representatives of the United States who administer the Government of Cuba. 
The Government of Cuba is, essentially, the President of the United States, the island being ruled by his subordinates who execute his orders, or their own, which he adopts if he does not revoke. It cannot be said that this government is organically independent of the United States, for the President enjoys his powers by virtue of his office, and in no respect either within or without the United States is that office separable from the Federal Government of which it is a co-ordinate branch. The Government of Cuba is rooted in Washington, not in Havana. It is an offshoot of the Executive Department of the United States projected into and holding its place in a foreign territory with the assent of Congress. Hence, although the island of Cuba is not within the jurisdiction of Congress, the Government of Cuba is subject to every power which the federal legislature is authorized to exert in regard to the Executive Department.

Whether Congress is competent to order this government to pass specific laws for the island, and thus legislate effectively for it through the medium of the Executive Department without bringing it technically within congressional jurisdiction, I do not discuss. The impropriety of this action should be a sufficent reason for avoiding it:

Our control over Cuba may be called "military" in view of its origin, the agencies by which it is chiefly managed, and its freedom from the restraints of municipal law, yet it is not properly identified with a military occupation of foreign territory contemplated by the laws of war. Our control should be, as it is, exerted less rigorously than a "military occupation," and in thus differentiating it I rely upon the persuasive ethics of.international law which discourage the application of belligerent right to a peaceful country. And Cuba is at peace, though prudence may forbid at present the diminution of our forces, and if need be the government may be called upon to display full military powers in the face of insurrection. I say "insurrection" advisedly, because at the moment our government was established in Cuba it rightfully demanded the obedience of the people.

While our control is less onerous than an ordinary military occupation, its activities are more varied and its responsibilities are heavier.

The conqueror's strict duty to the inhabitants of the territory is performed when he affords them such liberty of action 
and protection as the exigencies of honorable warfare permit. Our duty in Cuba is to govern a friendly country. And this brings us to the grave question as to the powers of our government over the lives and fortunes of the people.

The fourth clause of the Joint Resolution of Congress, April 20, 1898 , reads: "The United States hereby disclaims any disposition or intention to exercise sovereignty, jurisdiction or control over said island except for the pacification thereof, and asserts its determination when that is accomplished to leave the government and control of the island to its people," and this was incorporated in the ultimatum delivered to Spain. "Pacification" is the master-word of the first part of the clause, and did this express a self-imposed law, we have broken it, for after stretching the word to the uttermost many of our acts in Cuba are hopelessly beyond its meaning. For example, the pacification of Cuba is not promoted by orders regulating the sponge fishery," and prescribing that civil marriages only. shall be legally valid." The truth is "pacification" did not prefigure the great responsibilities and the sequent powers of the United States in taking charge of Cuba, and so far from breaking faith by assuming temporarily complete control they have performed a duty necessitated by the absence of a local government.

The Government of Cuba is not bound by any law of the United States in its dealings with the people, nor by any law of the old régime which it may choose to alter or repeal. Yet, although it is not restrained by a municipal constitution of which the governed may take advantage, I should hesitate to define this government as despotic in theory, not merely for sentimental reasons, but rather because it is required by principle as well as by treaty to respect the dictates of international law.

The government, however defined, is charged with the duty. of administering Cuba and abating the grosser evils of the Spanish regime. And doubtless there is a field for remedial action beyond these imperative duties. But zeal for reform, a preference for the American way, which we understand over the Spanish way which we do not understand, should not lead to disturbances of fundamental law and inveterate custom unbecoming the office of a provisional ruler.

${ }^{1}$ General Brooke's Civil Report I, Iog.

${ }^{2} \mathrm{Id} .44$. 
Our occupation is terminable at our discretion; and within our power is the method of ending it, though the brutal way of abandonment is practically out of the question.

The United States may end the present occupation by changing its character to sovereign proprietorship-by annexing the island. This can be accomplished only by Congress; the treaty making body, which usually enlarges the United States, being without jurisdiction in this case because there is no other government competent to make a cession.

Annexation by formal act would be the orderly course, but might not the same result be reached by Congress legislating for the island? We are so accustomed to enlarge our dominion by formal consent of the titular sovereign of the desired territory that we are apt to lose sight of the truth that land may be annexed as well by the actual assumption of jurisdiction by the President and Congress as by a treaty of cession. Said the Supreme Court, "Who is the sovereign, de jure or de facto, of a territory is not a judicial, but a political question, the determination of which by the legislative and executire departments of any government conclusively binds the judges, as mell as all other officers, citizens and subjects of that government. This principle has always been upheld by this court, and has been affirmed under a great variety of circumstances." And Chief Justice Marshall said: "If those departments which are intrusted with the foreign intercourse of the nation, which assert and maintain its interests against foreign powers, hare unequivocally asserted its rights of dominion over a country of which it is in possession, and which it claims under a treaty; if the legislature has acted on the construction thus asserted, it is not in its own courts that this construction is to be denied. A question like this respecting the boundaries of nations, is, as has been truly said, more a political than a legal question, and in its discussion, the courts of every country must respect the pronounced will of the legislature."

The principle of Marshall's opinion covers a broader field. than the disputed boundaries of land ceded by treaty, which was the case in Foster v. Neilson. If the army of the United States seizes foreign land; if a treaty of peace does not mention hostile territory then occupied by our forces, thereby recogniz.

3Jones v. U. S., I3I U. S. 202, 2 I2.

Foster v. Neilson, 2 Peters 253, 309, cited in U. S. v. Lynde, II Wallace 632,638 . 
ing our possession by the operation of the principle of uti possidetis; if American officers take possession of unoccupied land in the name of the Republic, Congress, by legislating for these territories, may effect their incorporation in the United States. Now Congress is at present without jurisdiction in Cuba, but the island is in possession of our forces. If, then, Congress shall choose to make laws for Cuba, the legislative and executive departments of our government will have asserted the perfect sovereignty of the United States, and the courts will follow their lead, provided the assertion be unequivocal.

Of course our courts would not recognize a statute of doubtful range as extending to Cuba. They would endeavor to construe a statute evidently intended to.be operative in the island as an exertion of exterritorial power over our citizens abroad, and not a law of the place. And, though this suggests a most delicate question, it is possible that a statute plainly directed to Cuba might be so trivial in itself or so markedly at variance with the pronounced attitude of Congress that the court would properly treat it as ultra vires rather than infer the tremendous consequence of an enlargement of the United States from such doubtful evidence of intention.

The method by which the United States are pledged to end their occupation of Cuba is to recognize a Cuban state. It is predicted that the pledge will be broken, or falsely kept by setting up a toy state that will cede the island to us in due form. Of these political forecasts I have only to say, at present, that I have yet to see the reason why the pledge should not be kept, and refuse to believe that the United States will play an hypocritical trick to gain an end which, if improper, should not be pursued, and, if proper, should be gained by the straightforward method of annexation by act of Congress.

III.

From the Cuban standpoint the island is in a singular position. Severed from Spain; not joined to the United States; not the territory of a Cuban state; Cuba is in some sense merely a region administered by a foreign master.

Yet although the island is not the seat of a state it possesses a marked characteristic of an organized society-a body of law: Spanish in origin, yet retaining its vitality after the withdrawal. of Spain; alterable by the government we have established, yet - never becoming United States law, this body is the law of the 
place, and the fact of its existence makes Cuba to some extent a political entity. To this law of the place, both civil and criminal, all persons in Cuba are subject, including all foreigners excepting our citizens whose connection with the army may subject them to the military laws of the United States.

What is the status of the people of Cuba, including in this class the Peninsular subjects of Spain who have not elected to retain Spanish citizenship in conformity with the provision of the Treaty of Paris?

On April 20, r898, Congress resolved "that the people of Cuba are, and of right ought to be, free and independent." In point of law, this resolution had no more effect in Cuba than a resolution "that the Sultan of Morocco has and ought to have but one wife" would bave in his palace. In point of fact, the resolution, so far as it dealt with the existing order of things, did not express a truth at the date of its passage-indeed, in the same breath Congress practically resolved to go war with Spain because the Cubans were not free and independent. Nor are they free and independent to-day.

The Cubans are no longer subjects of Spain. Divested of Spanish nationality, by their own consent in the case of Peninsulars who have cast their lot with $\mathrm{Cuba}$, by the act of Spain in the case of Cuban-born subjects who were not given a right of election, they can be reintegrated only by complying with the provisions of Spanish law. The situation of men of Cuban birth who prefer Spanish citizenship is indeed a hard one, yet they cannot question the legality of the rupture of the old allegiance, for with the right of a sovereign to cede territory is coupled the right to disavow further responsibility for its inhabitants.

The Cubans are not, of course, citizens of the United States, nor are they technically our subjects, though if they can be said to owe allegiance to any political head it is to the government we have set over them. They have been called "citizens of Cuba," and so long as we understand their citizenship to be of that singular kind that does not involve membership in the political society we call a state, we may accept this classification, which seems to be approved by the Treaty of Paris. The Ninth Article declares that if the Peninsular subjects of Spain residing in ceded or relinquished territories shall not within a certain time ceclare an intention to retain their allegiance, "they shall be held to have renounced it, and to have adopted the nationality of the territory in which they may reside." "Nationality" is 
evidently used in a political sense, and in order to give effect to this meaning in Porto Rico and the Philippines we must assume that the persons mentioned adopt the nationality of the United States, because as the United States have annexed these islands it would be as absurd to speak of Porto Rican or Philippine nationality as of Alaskan or New Mexican nationality. But as the United States have not annexed Cuba we can give effect to the provision in its regard only by accepting the theory of a Cuban nationality for what it is worth.

A familiar principle of public law is that a radical change of government, however it may alter the public order of things, shall, of itself, affect private relations and rights as little as possible.

The application of this principle to the domestic affairs of Cuba does not call for special consideration. It is sufficient to observe that rights vested under the old laws are not to be 2brogated; that the old laws themselves endure unless they are altered by the provisional government; and that the people must receive from this government protection to person and property. Beyond these domestic affairs there are interests growing out of the intercourse between Cuba and the world at large, and to these the principle should be applied wherever practicable.

Cuba is still within the domain of private international law, and I assume that the courts of foreign nations, including, of course, our own, will generally continue to apply their rules in international controversies, involving contracts, wills, marriages and the like, as though the island had not undergone a political change.

Whether a foreigner may sue a person in the courts of the latter's country depends upon the local law, and it will be assumed that foreign courts heretofore open to Cuban subjects of Spain will not be closed to Cuban protegés of the United States. It is especially important that Cubans shall not lose any privileges in American courts because the United States have placed them in an anomalous position, and where proof of alienage is sufficient to confer jurisdiction there will be no question as to the propriety of entertaining their suits, for unquestionably they are aliens. Because the right to sue is accorded "to citizens or subjects of a foreign state," by the Constitution of the United States, an effort has been made to bar Cubans from the fedetal courts, but Judge Lacombe has decided in their favor, saying of the defendant's contention: 
"There is certainly nothing in all this which lends any color to the proposition that the plaintiff is not a foreign citizen. Even the brief memorandum of opinion in Stuart v. City. of Easton (156 U.S. 46), gives no support to demurrant's contention. One may be puzzled to determine upon what theory it was held in that case that a "citizen of London, England," is not a "foreign citizen;" but assuming, as suggested, that it is because London is not a free and independent community, but owes allegiance to the British Crown, the decision has no application to the case at bar, since the political branch of this government has found as a political fact that the people of the island of Cuba "are free and independent." May not Judge Lacombe's conclusion be upheld without lending judicial sanction to the fiction of Cuban independence? Even if we attribute to Cubans a sort of citizenship they are neither citizens nor subjects of a "foreign state," for there is no 'state" of Cuba, and the government we have established is not "foreign." As the letter of the Constitution must be departed from to some extent to effectuate its meaning, why should not the provision be interpreted, as a whole, in the broad spirit which animates it, and the courts be declared open to persons who show that they are not citizens of the United States?

Besides international controversies determinable in the courts, there are private interests recognized by the law and custom of nations as being the proper subjects of diplomatic assistance or negotiation, and for which individuals may request the good offices of their government. Regarding the common protection and privileges to which persons in foreign conntries are entitled by international law, the diplomatic and consular offices of the United States may be exerted in behalf of Cubans as nearly to the extent of their exertion for our own citizens as the rules of foreign governments and our own permit.

Generally speaking, our concern for Cubans abroad cannot be properly questioned by a foreign government, for these reasons: Because the relation between a state and a person for whom it claims protection is no concern of a foreign state unless it claims him as its own citizen, and we shall not meet this embarrassment because Spain has completely denationalized her Cuban subjects: Because as foreign governments are entitled, as we shall see, to view the United States as the pro-

${ }^{3}$ Betancourt v. Mutual Reserve Fund Life Association, N. Y. Law Journal, May 15, rgoo. 
tector of the interests of their subjects in the island, they will not disavow the reciprocal duty of safeguarding Cuban interests in their own dominions.

The fact that Cubans cannot receive United States passports, which are issuable to citizens only, is not especially detrimental. The State Department has approved the issuance of the following consular certificate to an American Indian: "The bearer of this document is a North American Indian whose name is Hampa. This Indian is a ward of the United States, and is entitled to the protection of its consular and other officials. He is not, however, entitled to a passport, as he is not a citizen of the United States. This consulate has the honor to request the Russian authorities to grant Hampa all necessary protection during his stay in Russia, and grant him permission to depart when he requires it." * The State Department may issue suitable certificates to Cubans-probably it has already done so-and these will be honored abroad as our Indian certificate seems to have been, and as the passports issued by Great Britain and France to persons not their citizens, but within their protection, are honored.

Whatever rights under Spanish treaties Cubans may have enjoyed abroad as Spanish subjects have been lost by the severance of Cuba from Spain. Whatever rights may be secured to them by the treaty of Paris are enforceable by the United States, at least during the term of their control. Whether the United States shall be disposed to request and be able to secure for Cubans the benefit of treaty rights in foreign lands enjoyed by their own citizens depends upon the nature of the particular right in question. There is no doubt that the benefit of our consular jurisdiction in non-Christian countries should be claimed for Cubans. On the other hand, it would be absurd for the United States to demand for them the fishing rights on the Northeast coast secured to the people or citizens of the United States by treaty with Great Britain.

\section{IV.}

The distinction between Cuba and the United States which we maintain as a matter of domestic law and polity is not altogether effective from the standpoint of foreign nations.

When a region is occupied by a foreign state, other states are not necessarily affected by the motive of the occupation, so far as their current intercourse is concerned, and, in their reasonable demand for a visible and responsible head to a

\footnotetext{
- Hunt's The American Passport, p 147
} 
country with which they deal, are entitled to treat the occupant as the sovereign for certain purposes. And it is the interest as well as the duty of the occupant to accept the proper responsibilities of the position, because if these be disavowed the country may be left without a government, and in this event a foreign state being unable to protect its lawful interests by negotiation, may at once employ adequate force.

From the standpoint of foreign nations Cuba is in some sense part of the United States, and the United States accept this conclusion of international law.

According to the first article of the Treaty of Paris already cited, "the United States will, so long as such occupation shall "last, assume and discharge the obligations that may, under "international law, result from the fact of its occupation, for "the protection of life and property." While this clause is part of a treaty with Spain, and does not import an agreement with any other nation, it is really but the acknowledgment of an independent obligation to all nations. And it may prove to be an inadequate acknowledgment, for if, perchance, there be any international duty not included in "the protection of life and property," the United States cannot honorably avoid the consequences of a breach of it by referring to the treaty as the measure of their responsibility.

In considering our duties to foreign nations in regard to Cuba we must first differentiate Spain from the generality in regard to the special agreements made with her in the Treaty of Paris. Apart from the law of the Treaty of Paris, by which Spain is particularly bound and benefited, she stands with the other nations in respect of international rights and obligations.

The foreign responsibilities cast upon an occupant in the case of occupation of hostile territory during war, when inevitable disorder may excuse unavoidable defaults, and when the ousted sovereign has still a legal title to the country, and may regain possession by reconquest or treaty, are broader and heavier in Cuba, where order reigns if not contentment, and whence the old sovereign has departed leaving the representatives of the United States in full control.

Without attempting to forecast the possible reclamations that may be made against the United States on Cuban account, it.should be understood by the Cubans that if the United States 
become liable for a pecuniary indemnity they will place the real burden where it belongs. If the injury be caused by the unlawful act or omission of United States citizens, the indemnity should be charged upon the Federal Treasury. On the other hand an indemnity due on account of the acts of Cubans should be charged to Cuba, and paid either out of insular revenues, or by Cuban obligations which the United States should guarantee to the creditor and enforce against the debtor.

Carman F. Randolph. 